Images in...

\title{
Neonatal percutaneous line tip position on supine radiography isn't always enough to verify position
}

\author{
Richard lain Hearn, Alan Charles Fenton
}

Royal Victoria Infirmary, Newcastle Upon Tyne, UK

Corresponding to Richard lain Hearn, rhearn@nhs.net

\section{DESCRIPTION}

Tip position is key in the placement of percutaneous long lines. We would however like to illustrate the pitfalls of relying on the apparent tip position in supine radiography.

Figure 1 shows a wired $28 \mathrm{~g}$ premicath, inserted via the saphenous. The tip lies in a central position at S1. Measurement prior to insertion suggested the tip lie in the upper lumbar region.

Total parental nutrition (TPN) ran for $48 \mathrm{~h}$ before a TPN blister was noted in the lower left quadrant. The line was felt to have been in an abdominal wall collateral. The lesion quickly resolved with line removal.

On review two points were noted which may have pointed to a mis-sited line.

1. The line was easily inserted to the externally measured distance but the x-ray showed the tip proximal to the expected site.

2. The line curves en route to $\mathrm{S} 1$.
We reviewed the previous 38 consecutively inserted saphenous lines. All with their tips within the abdomen took a straight route.

Until recently all lines in our unit were imaged with contrast. It is likely this would have alerted us to the position, as Cartwright ${ }^{1}$ described. Many units currently do not use contrast due to iodine content. We therefore suggest in situations in lower limb lines where the tip has not reached the anticipated position on x-ray despite inserting an appropriate length and/or where the line has not followed a straight route, a lateral film will determine whether the line is in the inferior vena cava or a collateral vein.

Competing interests None.

Patient consent Not obtained.

\section{REFERENCES}

1. Cartwright DW. Central venous lines in neonates: a study of 2186 catheters. Arch Dis Child Fetal Neonatal Ed 2004;89:F504-8.

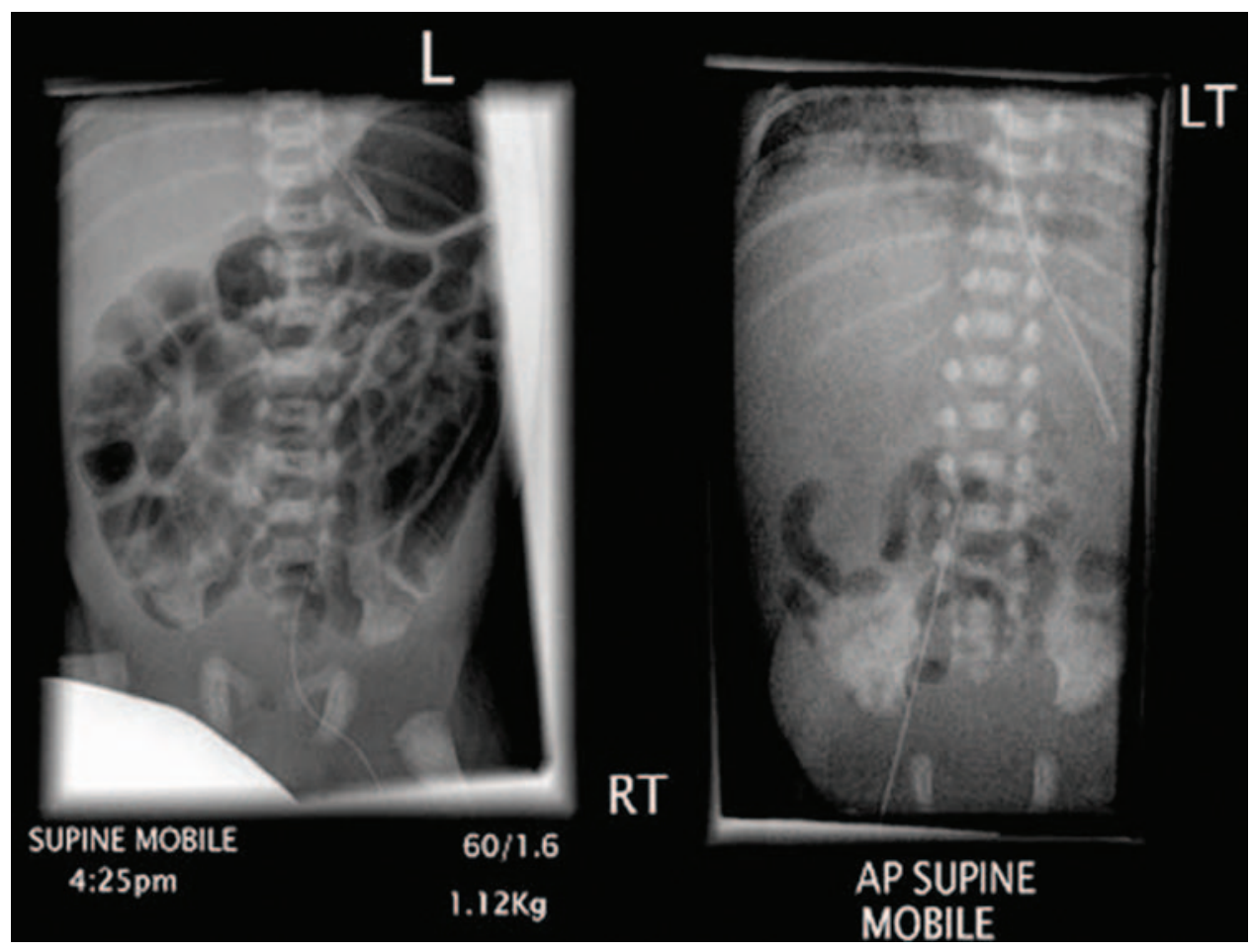

Figure 1 Saphenous lines. Anomalous route on left. Normal route on right. 


\section{BMJ Case Reports}

This pdf has been created automatically from the final edited text and images.

Copyright 2011 BMJ Publishing Group. All rights reserved. For permission to reuse any of this content visit http://group.bmj.com/group/rights-licensing/permissions.

BMJ Case Report Fellows may re-use this article for personal use and teaching without any further permission.

Please cite this article as follows (you will need to access the article online to obtain the date of publication).

Hearn RI, Fenton AC. Neonatal percutaneous line tip position on supine radiography isn't always enough to verify position. BMJ Case Reports 2011;10.1136/bcr.02.2011.3838, date of publication

Become a Fellow of BMJ Case Reports today and you can:

- Submit as many cases as you like

- Enjoy fast sympathetic peer review and rapid publication of accepted articles

- Access all the published articles

- Re-use any of the published material for personal use and teaching without further permission

For information on Institutional Fellowships contact consortiasales@bmjgroup.com

Visit casereports.bmj.com for more articles like this and to become a Fellow 